Review

\title{
General Bearing of Students with Sustainable Satisfaction in Higher Institution of Learning
}

\author{
Ilker Etikan, Kabiru Bala, Ismail Taylan BAKIR and Meliz Yuvalı \\ Department of Biostatistics, Faculty of Medicine, Near East University, Cyprus
}

Corresponding Author:

Ilker Etikan

Department of Biostatistics,

Faculty of Medicine, Near East

University, Cyprus

Email: ietikan@gmail.com

ilker.etikan@neu.edu.tr

\begin{abstract}
The research study was formulated based on promoting a healthy and conducive environment in other to assist student to get satisfied with the process of learning endeavor. The priority for any University is to create enabling healthy environment for conducive atmosphere for learning to take place in other to give and get the best from their student. This study covers a sample of 227 student from Near East University Cyprus, closed ended question was design to generate the response of student from the University, after then analysis was carry out via SPSS version 18.0. Statistical analysis perform with the SPSS were Descriptive Statistics, Chi-Square test, Independent Sample t-Test, One way Anova and correlation. Student information used in generating the responses were place of residence, gender, on-scholarship and not on scholarship student, continent background to mentioned but few.
\end{abstract}

Keywords: Facilities, Structures, Recreational Activities, Satisfaction, Staffs, Student

\section{Introduction}

Tertiary Institution is place were intelligent people devote most of their time in other to achieved a particular goal, these people comprise of Management Staffs, Academic Staffs and Students. Thus mentioned play a fundamental role for the development of a school setting especially, the staffs and lecturer is their permanent place of survival until they are retired either by out of service or by death while for the student after graduation they leave for job or further their education in different school. The higher learning institution is a place where student are expected to learn by getting the best and give the best. This could be achieved through healthy and conducive environment with good structures and facilities, safety of student lives, smoking free life and drinking, healthy sleep, relationship, academic performance to quantified but limited. Any university that provide the aforementioned for their students will achieved the best from the student and will compete globally with other standard school.

\section{School Structure, Facilities and Staff}

For a viable satisfaction of student in higher institution of learning the management need to provide basic structure, facilities and qualified staff especially the academic staffs. Higher quality of student output need higher quality of impute, when there is low quality of equipment it will reduced the fastness of lecturers productivity to their student, it takes more time to do a job with old equipment than new equipment. It is very urgent and necessary for tertiary institutions to make provisions for toilets in every section of staff offices, laboratories, library, lecture halls, also constant provision of water at each block or building will make those in charge of taking care of the building and toilets to provide a better services for conducive environment, without this, the schools environment with the growing numbers of students in our higher institutions is going to be likely in danger for global outbreaks like cholera, malaria as well as to offer short distance and to allowed student from disease (Abraham, 2016; Katherine et al., 2011). The school management has to increase the student awareness on the value of prevention and healthy lifestyle. The mission of health centers in our school has to be redefined to consist not just treating medical problems but also to manage serious chronic situations and to promote healthful lifestyles. Staffs and lectures recruitment for good delivering with sustainable satisfaction to student should be based on merits, during recruitment exercise, background study of person should be considered before employment, competency, skills, experiences, technical qualities should be reflected during the period of recruitment which is very vital for student success. 


\section{Infrastructure and Laboratory}

Construction, repairing and maintaining of building, laboratories and other field site with obtaining of learning equipment are part of infrastructural requirement for learning in education. Student will be affected without a conducive atmosphere, lecture halls, equipment and structures (Salim, 2014; Ferdosi et al., 2013). Physical location of learning facilities can influences and improve both the staff and student learning, it will make the staff deliver very well. Information communication technology, standard library with e-facilities, good materials for learning such as text books online books will also assist.

\section{Quality Health Care Services}

It is very challenging to define and measure health care service quality because health is a product that cannot be physically touched, felt, viewed, counted or measured. The quality of health care service depends on services process of the school management. Nowadays is very difficult to produce a consistent health care service in our schools because of the challenges from the Government most especially the head of schools (FIHCSQ, 2014; Fatima and Avan, 2002). The tertiary institutions most have professionals (nurses, physicians) in delivering of health services in any schools setting for patients with different need. Quality in health care services operation are very difficult to established because professional render their services differently, factors differs base on individual experiences, abilities and personalities. Health in the broadest sense provides critical support to the academic mission. Positive health status could builds and increased student by having greater ability and readiness to learn and participate fully in all meaningful educational experiences inside and outside the classroom. Tertiary institution need in addition medical and counseling services, our schools need to have counseling centers to offer student such as stress reduction programs, educational programs and materials for parents/families (Kylie et al., 2013; Mehrdad, 2009; Pedro and Araujo, 2010). Campuses should target health education programs for faculty, Teachers and students. Not waiting for students to come to them. Also undertaking problems relating to suicide prevention, sexual attack prevention and reducing the stigma around mental health problems (Katherine et al., 2011; Mehrdad, 2009; Osland et al., 2000). Our Schools health center workers' salaries need be well paid to supplement their demands, including primary care providers. Schools health centers should be adequately provided with new technology, facilities and also taking care with sustaining principles of the facilities need to be improved.

\section{School Educational Service}

Student stable satisfaction will bring success through the knowledge and skills from what they learn. This mean the school should organized standard curriculum with administration that will change student in schools, new courses in curriculum assist in providing change to new knowledge, ensuring of quality and responsive curriculum. The curriculum of school most meet the standard expectation of a school because good curriculum in school developed the vital competence to response to the need of student. Curriculum evaluation response entails more than just simple changes on paper, the nature of our curriculum is to develop new content without been able to shed the previous one (David et al., 2014; FIHCSQ, 2014). Management should provide recreational activities for both the team event and individual event because all work or educational activities without play make individual a lifeless person, after sport and shower student brain will be fresh and ready for assimilation. School management should encourage further training of our lecturers by sufficient monitoring their carrier advancement, encouragement of seminar/conferences and research. Incentive should be given to lecturers for research and service to improve teaching learning. Lack of reward sometime make the lecturers to be reluctant as a result it will affect the student performance. School accreditation by management help in promoting competency and trust because is a device for not only assessment of our higher institutional performance but more fundamental for attaching public confidence. Accreditation requires facilities to generate evidence in the support of performance objectives in relation to what will improved the standard of school especially side of the lecturers. Standard accreditation will assist in reducing some problems with high cooperation of professional bodies and constant visit by the body, schools settings will change for better (Fatima and Avan, 2002; Katherine et al., 2011; Osland et al., 2000).

\section{Methodology}

The questionnaire survey was mainly design for student of Near East University Cyprus with the view of discovering the sustainable satisfaction life of student considering student gender, programmes, performances and so on. A restricted closed questions was used in generating the response, were sample selected covers student from oncampus, near campus and distance campus. About 227 selfadministered questionnaires was retrieve from 250 respondent. Male student accounted for $61.7 \%$ and female with $38.3 \%$. Also student leaving on campus were $15.9 \%$, student around near campus showed $41.0 \%$ and student staying far away from school gave $43.2 \%$. Apart from the descriptive different hypotheses test was conducted which reveal that there was successful satisfaction of student performance in the school general structure and setting. The descriptive and hypotheses result analysis conducted in this research was done with the assistance of Statistical Software Package called Statistical Package for Social Sciences (SPSS).

Cross tabulation between student years of stay with their performances showed no effect $\left(\chi^{2}=3.176, p=\right.$ 0.529 ). Place of residence has influence on student performance $\left(\chi^{2}=12.355, p=0.015\right)$. Association 
between gender with performance of student showed no effect on student performance $\left(\chi^{2}=1.321, p=0.517\right)$. Also sponsorship of student with their performances indicate no effect $\left(\chi^{2}=5.486, p=0.241\right)$.

\section{Interpretation of Result Analysis for Table 3}

Independent sample $t$ test violated the assumption which resulted to application of Mann Whitney test. The p-value (0.301) shows that there was no significant difference between successful satisfaction of student performance based on quality of lectures while between successful satisfaction of student performance based on facilities and structure also indicate there is no significant difference $p$ value (0.739). Student age with their place of residence showed no significant difference p-value (0.093). Means no specification for age (young or older) to leave either oncampus or off-campus. Student performance using One way Anova of Kruskal Wallis test showed that there was no significant difference between CGPA performance with continent were student are coming from means they were equal with p-value (0.777).

\section{Research Question and Hypothesis}

Is there any significant evidence to suggest that there is linear correlation between student age on monthly expenditure:
$H_{0}$

$\mathrm{H}_{1}$

: There is no correlation between student age with monthly expenditure $\left(H_{0}: \rho=0\right)$

: There is correlation between student age with monthly expenditure $\left(H_{1}: \rho \neq 0\right)$

Test Statistics : Bivariate Spearman Rank Correlation of age among student monthly expenditure

The assumption for using Pearson Correlation did not hold because the scatter plot data is not linear, that mean there is no linear relationship. Alternative for using the correlation was Spearman Rank Correlation therefore the result was found to be 0.095 indicating a very week positive correlation between student age with monthly expenditure. The p-value result is 0.161 which is greater than alpha value $(0.05)$. We therefore accept the null hypothesis and conclude that there was no correlation between student age on their monthly expenditure.

\section{Conclusion}

This study examines general bearing of students with sustainable satisfaction in higher institution of learning from different angles. The descriptive statistics result from Table 1 reveal student with their place of residence off-campus recorded more support than the leaving campus student.

Table 1. Descriptive statistics of survey output

\begin{tabular}{|c|c|c|c|c|c|}
\hline \multirow[b]{2}{*}{ Gender } & & \multicolumn{4}{|c|}{ Participant res } \\
\hline & & Frequency & $(\%)$ & Valid (\%) & Cumulative (\%) \\
\hline & Male & 140 & 61.7 & 61.7 & 61.7 \\
\hline & Female & 87 & 38.3 & 38.3 & 100.0 \\
\hline & Total & 227 & 100.0 & 100.0 & 100.0 \\
\hline \multirow[t]{5}{*}{ Age category } & Middle age (21-50) & 150 & 66.1 & 66.1 & 66.1 \\
\hline & Old age $(50+)$ & 4 & 1.8 & 1.8 & 67.9 \\
\hline & Young age $(0-20)$ & 65 & 28.6 & 28.6 & 96.5 \\
\hline & Missing data & 8 & 3.5 & 3.5 & 100.0 \\
\hline & Total & 227 & 100.0 & 100.0 & 100.0 \\
\hline \multirow[t]{4}{*}{ Residence } & Near campus & 93 & 41.0 & 41.0 & 41.0 \\
\hline & Distance from campus & 98 & 43.2 & 43.2 & 84.1 \\
\hline & On campus & 36 & 15.9 & 15.9 & 100.0 \\
\hline & Total & 227 & 100.0 & 100.0 & 100.0 \\
\hline \multirow[t]{3}{*}{ Transportation } & Agreed & 133 & 58.6 & 58.6 & 58.6 \\
\hline & Disagreed & 94 & 41.4 & 41.4 & 100.0 \\
\hline & Total & 227 & 100.0 & 100.0 & 100.0 \\
\hline \multirow[t]{3}{*}{ Duration of stay } & Fresh student & 106 & 46.7 & 46.7 & 46.7 \\
\hline & Old student & 121 & 53.3 & 53.3 & 100.0 \\
\hline & Total & 227 & 100.0 & 100.0 & 100.0 \\
\hline \multirow{3}{*}{ Programme } & Postgraduate & 59 & 26.0 & 26.0 & 26.0 \\
\hline & Undergraduate & 168 & 74.0 & 74.0 & 100.0 \\
\hline & Total & 227 & 100.0 & 100.0 & 100.0 \\
\hline \multirow[t]{5}{*}{ Grading system } & Good student & 96 & 42.3 & 42.3 & 42.3 \\
\hline & Very good student & 35 & 15.4 & 15.4 & 57.7 \\
\hline & Week student & 94 & 41.4 & 41.4 & 99.1 \\
\hline & Missing & 2 & 0.9 & 0.9 & 100.0 \\
\hline & Total & 227 & 100.0 & 100.0 & 100.0 \\
\hline \multirow[t]{5}{*}{ Ethnicity } & White America & 1 & 0.4 & 0.4 & 0.4 \\
\hline & Asian & 10 & 4.4 & 4.4 & 4.8 \\
\hline & Africa & 190 & 83.7 & 83.7 & 88.5 \\
\hline & Europe & 13 & $5.7 \mathrm{a}$ & 5.7 & 100.0 \\
\hline & Middle belt & 227 & 100.0 & 100.0 & 100.0 \\
\hline \multirow{5}{*}{ Religion } & Islam & 94 & 41.4 & 41.4 & 41.4 \\
\hline & Christianity & 131 & 57.7 & 57.7 & 99.1 \\
\hline & Buddhism & & 0.4 & 0.4 & 99.6 \\
\hline & Others & 1 & 0.4 & 0.4 & 100.0 \\
\hline & Total & 227 & 100.0 & 100.0 & 100.0 \\
\hline
\end{tabular}


Male responded has higher percentage than female counterpart. However based on programmer undergraduate student accounted for higher response percentage than the postgraduate student. In terms of student performances it shows student are doing very well compare to the weak student, most of them were new in the school. Table 2 result for cross tabulation reveal that student years of stay with their performances indicated no effect while Place of residence has influence on student performance. More so involvement between gender with performance of student showed on no account result on student performance and also sponsorship of student with their performances point out no influence. The result from Table 3 shows that there is no significant difference between successful satisfaction of student performance based on quality of lectures while between successful satisfaction of student performance based on facilities and structure also indicate there is no significant difference.

Table 2. Cross tabulation analysis

Years of stay has no effect with student performance Chi-Square value (3.176) p-value (0.529)

\begin{tabular}{|c|c|c|c|c|c|}
\hline & & \multicolumn{4}{|c|}{ Performance } \\
\hline & & Good & Very good & Weak & Total \\
\hline \multirow[t]{10}{*}{ Years of stay } & 1st year & & & & \\
\hline & Count & 48 & 16 & 40 & 104 \\
\hline & $\%$ within years of stay & $46.2 \%$ & $15.4 \%$ & $38.5 \%$ & 100 \\
\hline & $\begin{array}{l}\% \text { within performance } \\
2 \text { nd year }\end{array}$ & $50.0 \%$ & $45.7 \%$ & $43.0 \%$ & $46.4 \%$ \\
\hline & Count & 32 & 10 & 28 & 70 \\
\hline & $\%$ within years of stay & $45.7 \%$ & $14.3 \%$ & $40.0 \%$ & 100 \\
\hline & $\begin{array}{l}\text { \% within performance } \\
\text { 3rd year }\end{array}$ & $33.3 \%$ & $28.6 \%$ & $30.1 \%$ & $31.3 \%$ \\
\hline & Count & 16 & 9 & 25 & 50 \\
\hline & $\%$ within years of stay & $32.0 \%$ & $18.0 \%$ & $50.0 \%$ & $100 \%$ \\
\hline & $\%$ within performance & $16.7 \%$ & $25.7 \%$ & $26.9 \%$ & $22.3 \%$ \\
\hline \multirow{2}{*}{\multicolumn{6}{|c|}{$\begin{array}{l}\text { Place of residence has effect with student performance Chi-Square value (12.355) p-value (0.015) } \\
\text { Residence }\end{array}$}} \\
\hline \multirow{12}{*}{ Residence } & & & & & \\
\hline & Count & 38 & 11 & 43 & \\
\hline & $\%$ within residence & $41.3 \%$ & $12.0 \%$ & $46.7 \%$ & $100 \%$ \\
\hline & $\%$ within performance & $39.6 \%$ & $31.4 \%$ & $45.7 \%$ & $40.9 \%$ \\
\hline & Distance campus & & & & \\
\hline & Count & 50 & 17 & 30 & 97 \\
\hline & $\%$ within residence & $51.5 \%$ & $17.5 \%$ & $30.9 \%$ & $100 \%$ \\
\hline & \%within performance & $52.1 \%$ & $48.6 \%$ & $31.9 \%$ & $43.1 \%$ \\
\hline & On-campus & & & & \\
\hline & Count & 8 & 7 & 21 & 36 \\
\hline & $\%$ within residence & $22.2 \%$ & $19.4 \%$ & $58.3 \%$ & $100 \%$ \\
\hline & $\%$ within performance & $8.3 \%$ & $20.0 \%$ & $22.3 \%$ & $16.0 \%$ \\
\hline \multicolumn{6}{|c|}{ Student gender has no effect on student performance Chi-Square value (1.321) p-value (0.517) } \\
\hline \multirow[t]{8}{*}{ Gender } & Male & & & & \\
\hline & Count & 56 & 24 & 60 & 140 \\
\hline & $\%$ within gender & $40.0 \%$ & $17.1 \%$ & $42.9 \%$ & $100 \%$ \\
\hline & $\%$ within performance & $58.3 \%$ & $68.6 \%$ & $63.8 \%$ & $62.2 \%$ \\
\hline & Female & & & & \\
\hline & Count & 40 & 11 & 34 & 85 \\
\hline & $\%$ within gender & $47.1 \%$ & $12.9 \%$ & $40.0 \%$ & $100 \%$ \\
\hline & $\%$ within performance & $41.7 \%$ & $31.4 \%$ & $36.2 \%$ & $37.8 \%$ \\
\hline \multirow{2}{*}{\multicolumn{6}{|c|}{$\begin{array}{l}\text { Student sponsorship has no effect on performance Chi-Square value (5.486) p-value (0.241) } \\
\text { Performance }\end{array}$}} \\
\hline & & & & & \\
\hline \multirow{9}{*}{ Performance } & Count & 52 & 30 & 13 & \\
\hline & $\%$ within performance & $54.7 \%$ & $31.6 \%$ & $13.7 \%$ & $100 \%$ \\
\hline & $\begin{array}{l}\text { \% within sponsorship } \\
\text { Very good student }\end{array}$ & $39.4 \%$ & $50.0 \%$ & $44.8 \%$ & $43.0 \%$ \\
\hline & Count & 17 & 8 & 7 & \\
\hline & $\%$ within performance & $53.1 \%$ & $25.0 \%$ & $21.9 \%$ & $100 \%$ \\
\hline & $\%$ within sponsorship & $12.9 \%$ & $13.3 \%$ & $24.1 \%$ & $14.5 \%$ \\
\hline & Weak student & & & 9 & \\
\hline & $\begin{array}{l}\text { Count } \\
\% \text { within performance }\end{array}$ & $\begin{array}{l}03 \\
67.0 \%\end{array}$ & $23.4 \%$ & $\begin{array}{l}9 \\
9.6 \%\end{array}$ & $\begin{array}{l}94 \\
100 \%\end{array}$ \\
\hline & $\%$ within sponsorship & $47.7 \%$ & $36.7 \%$ & $31.0 \%$ & $42.5 \%$ \\
\hline
\end{tabular}


Table 3. Parametric and non-parametric test of independent sample t-test and Anova

Independent sample t-test/ one way Anova

\begin{tabular}{|c|c|c|c|c|c|c|c|}
\hline & Respondent & $\mathrm{N}$ & Median & Minimum & Maximum & Assumption & Alternative/ p-value \\
\hline \multirow[t]{2}{*}{$\begin{array}{l}\text { CGPA is improved by } \\
\text { lecturers contribution }\end{array}$} & Agreed & 172 & 3.8000 & 1.50 & 3.700 & \multirow[t]{2}{*}{$\begin{array}{l}\text { Not normally } \\
\text { distributed }\end{array}$} & \multirow[t]{2}{*}{$\begin{array}{l}\text { Mann-Whitney value } \\
(3889.000) p=0.301\end{array}$} \\
\hline & Disagreed & 50 & 3.6000 & 1.50 & 3.700 & & \\
\hline
\end{tabular}

$p>\alpha$ there is no statistical significant difference, CGPA of student based on

qualified lecturers are equal to those with no qualified lecturers

$\begin{array}{llllllll}\begin{array}{l}\text { CGPA is improved by } \\ \text { structure/facilities }\end{array} & \text { Agreed } & 172 & 3.8000 & 1.50 & 3.700 & \begin{array}{l}\text { Not normally } \\ \text { distributed }\end{array} & \begin{array}{l}\text { Mann-Whitney value } \\ (3983.000) p=0.739\end{array} \\ & \text { Disagreed } & 50 & 3.6000 & 1.50 & 3.700 & \end{array}$

$p>\alpha$ there is no statistical significant difference, student whom agreed that facilities/structures improve their performance are equal to those that don't agreed

$\begin{array}{llllllll}\begin{array}{l}\text { Age among place } \\ \text { of residence }\end{array} & \text { Near campus } & 90 & 23.00 & 18 & 54 & \begin{array}{l}\text { Not normally } \\ \text { distributed }\end{array} & \begin{array}{l}\text { Kruskal Wallis } \\ p=0.093\end{array} \\ & \text { Distance campus } & 67 & 3.8000 & 17 & 58 & \end{array}$

$\begin{array}{lllll}\text { On-campus } & 35 & 22.00 & 18 & 33\end{array}$

$p>\alpha$ Place of residence 1 place of residence $2=$ place of residence 3 ,

there is no significant difference between age among their place of residence

$\begin{array}{lllllll}\text { N. America } & 20 & 3.5000 & 2.50 & 4.60 & \text { Not normally } & \text { Kruskal Wallis } \mathrm{p}= \\ \text { Europe } & 62 & 3.8000 & 1.50 & 4.50 & \text { distributed } & 0.777 \\ \text { Antarctica } & 4 & 3.8000 & 3.60 & 3.90 & & \\ \text { Africa } & 104 & 3.8000 & 1.60 & 3.700 & & \\ \text { S. America } & 5 & 3.9000 & 2.00 & 4.00 & & \\ \text { Australia } & 16 & 3.000 & 1.50 & 4.40 & & \\ \text { Asia } & 7 & 3.8000 & 1.80 & 3.700 & & \end{array}$

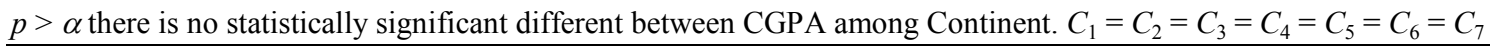

Student age with their place of residence shows no significant difference, means no specification for age (young or older) to leaving either on-campus or offcampus. Student performance using one way Anova of Kruskal Wallis test shows that there is not at all significant difference between CGPA performance with continent were student were coming from, entails equal.

\section{Recommendations}

Based on this result I recommend the management should keep to the good structure and facilities with the sustaining philosophy. Also addition of human resources academic and none academic. Lecturer Should be encourage on research seminars and let there be reward for that. The management should provide drugs and make the prices affordable in the health department (Hospital). Again standard individual and single event facilities for recreational activities to develop sport need to be put in place. And last management should try and reduce student hard ship especially cost of accommodation and also to introduced campus less price for student.

\section{Acknowledgement}

We would like to thank the students of Near East University who volunteered for our surveys in this research.

\section{Author's Contributions}

All authors equally contributed in this work.

\section{Ethics}

This study was conducted on students within the University. Since there was no invasive procedure, the ethics committee was not consulted but only with permission from the university administration. The study is a cross-sectional study, with the aim of determining the level of knowledge.

\section{References}

Salim, 2014. The relationship between student engagement and academic achievement. GUNUC Int. J. Trend Education Implication.

David, M., B. Petra, B. Ceri and B.M. Miph, 2014. Health care seeking behavior and challenges in utilising health facilities in Wakiso district Uganda. African Health Sci.

FIHCSQ, 2014. Factors influencing health care service quality. Int. J. Health Policy Manage.

Abraham, F., 2016. Medical Education in the United States and Canada: A Report to the Carnegie Foundation for the Advancement of Teaching (Classic Reprint). 1st Edn., Fb \&C Limited, ISBN-10: 1334662975, pp: 374. 
Fatima, Z. and J. Avan, 2002. Demographic, socioeconomic and environmental determinants of utilisation of antenatal care in a rural setting of Sindh, Pakistan. J. Park Med. Assoc., 52: 138-142.

Ferdosi, M., H. Afshar and N.M. Hosseini, 2013. The impact of top management turnover on quality management implementation. Med. Arch., 67: 134-40.

Katherine, D.H., J.A. Mayer, S. Gabbard, R.G. Kronick and S.C. Roesch et al., 2011. Impact of individual-, environmental- and policy-level factors on health care utilization among US farmworkers. Am. J. Public Health, 101: 685-692.
Kylie, M.S. C. Ellie and A.P. Crookes, 2013. Measuring research 'impact' for academic promotion: issues from the literature. J. Higher Educ. Policy Manage., 35: 410-420.

Mehrdad, R., 2009. Health system in Iran. Japan Medical Association $\mathrm{J}$.

Osland, J., D. Kolb and I. Rubin, 2000. Organizational behaviour an experimental approach 7th upper Saddle River. Organizational Behaviour Nj Prentice.

Pedro, D. and C.J. Araujo, 2010. Channels for improving performance form leaving on-campus. J. Bus. Educ. 